and low set ears, clinodactyly and other abnormalities of fingers and toes, and cryptorchidism or micropenis or both.

In most cases with $12 p-$ syndrome a larger deletion than in our patient was present, mostly including band $12 \mathrm{p} 12$. It is quite clear, however, that our proband has several features in common with the $12 \mathrm{p}$ deletion syndrome. Patients with a ring chromosome 12 have also been reported. ${ }^{5}{ }^{6}$ They have several features in common with the $12 p$ deletion syndrome and with our patient. The clinical features in these patients are ${ }^{p}$ : failure to thrive, mental retardation, epicanthus, 'cupped', low set ears, ogival palate, short webbed neck, low hairline, and cryptorchidism. In the ring chromosome cases a partial deletion of $12 \mathrm{p} 13$, similar to that in our patient, is present.

Regarding the enzyme lactate dehydrogenase $\mathrm{B}$ (LDHB), no reduction in activity was noted in our patient. Decreased activity was found in the $12 p$ deletion cases ${ }^{4}$ but not in the ring chromosome 12 case of Zuffardi et al. ${ }^{6}$ This seems to be in accordance with the gene localisation of LDHB at $12 \mathrm{p} 12$ and points to a similar $12 \mathrm{p}$ deletion in our patient as in the ring chromosome 12 case of $\stackrel{\mathbb{P}}{?}$ Zuffardi et al. $^{6}$

\section{References}

${ }^{1}$ Smith A, Fraser IS, Elliott G. An infertile male with balanced Y;19 translocation. Review of Y;autosome translocations. Ann Genet (Paris) 1979;22:189-94.

${ }^{2}$ Mattei JF, Mattei MG, Coignet J, Giraud F. Y/autosome translocation and complex chromosome rearrangement in cridu-chat syndrome. J Med Genet 1978;15:154-7.

${ }^{3}$ Orye E, Craen M. Complex chromosomal rearrangement: $(Y \mathrm{p}+; 4 \mathrm{q}-)$ translocation and ring chromosome of the $4 \mathrm{q}-$ chromosome. Ann Genet (Paris) 1983;26:47-9.

4 de Grouchy J, Turleau C. Atlas des maladies chromosomiques. 2nd ed. Paris: Expansion Scientifique Française, 1982.

${ }^{5}$ Scribanu N, McCullars EB, Baumiller RC, Colon AR. The syndrome of ring chromosome 12. Am J Med Genet 1980;5:16570.

${ }^{6}$ Zuffardi O, Danesino C, Poloni L, Pavesi F, Bianchi C, Gargantini L. Ring chromosome 12 and latent centromeres. Cytogenet Cell Genet 1980;28:151-7.

Correspondence and requests for reprints to $\mathrm{Dr} E$ Orye, Laboratory of Cytogenetics, Department of Pediatrics, Ghent State University, De Pintelaan 185, 9000 Ghent, Belgium.

\title{
Interstitial deletion of the long arm of chromosome 11
}

\author{
J M KLEP-DE PATER, H F DE FRANCE, AND J B BIJLSMA \\ Clinical Genetics Centre, PO Box 18009, 3501 CA Utrecht, The Netherlands.
}

SUMMARY A girl with an interstitial deletion of the long arm of chromosome 11 is described. The patient was mildly mentally retarded and showed some facial dysmorphic features, including hypertelorism, ptosis, and cleft palate.

Since Jacobsen et $a^{1}$ reported a family with a terminal deletion 11q, about 30 other cases have been published. These cases were all severely mentally retarded and presented with characteristic craniofacial anomalies: trigonocephaly, epicanthus, ptosis, flat nasal bridge; short bulbous nose with anteverted nostrils, triangular shaped mouth, retrognathia, and low set malformed ears. In all but one of the reported cases a de novo deletion of $11 \mathrm{q}$, with loss of at least the terminal region $\mathrm{q} 24 \rightarrow \mathrm{qter}$, was present. De novo interstitial deletions of the long arm of chromosome 11 have been reported in four infants by Taillemite et $a l^{2}{ }^{2}$ Sørensen et $a l,{ }^{3}$

Received for publication 11 August 1984. Accepted for publication 17 August 1984
McPherson and Meissner, ${ }^{4}$ and Bateman et al. ${ }^{5}$ Two of these cases were mildly mentally retarded and had trigonocephaly, hypertelorism, short bulbous nose, and high and narrow palate. In three cases low set ears were also present. In the case of Bateman et $a l,{ }^{5}$ who presented with Peter's anomaly, neither mental retardation nor dysmorphic signs were noted.

We report a girl with only mild mental retardation and some of the above mentioned phenotypic $N$ features in whom an interstitial deletion of the long $N$ arm of chromosome 11 was found.

\section{Case report}

The proband was the only child born to a young woman, who was reported to take drugs and drank alcohol in unknown quantities throughout pregnancy. The proband was removed from the custody of her mother and placed under the care of the juvenile court. According to the rules of this organisation no further information on the mother can be published 
here. The father is unknown. Birth weight and length were not noted. Five days after birth the child was admitted to the Department of Paediatrics of a local hospital because of dyspepsia, Clinical examination at that time revealed a bifid uvula and a submucous palatal cleft. Her weight was $2350 \mathrm{~g}$.

Re-examination at the age of 7.9 years showed a normally sized girl, height $123 \mathrm{~cm}$ (10th centile), weight $22.0 \mathrm{~kg}$ (10th centile), and head circumference $51 \mathrm{~cm}$ (50th centile) with hypertelorism, right ptosis, a bulbous nose with anteverted nostrils, large mouth, bifid uvula, and high arched and narrow palate (fig 1). Moreover, bilateral pes planovalgus and an increased space between the first and second toes were noted. Neurological examination revealed mild hypotonia with low reflexes. Electroencephalogram showed a diffuse non-specific abnormal pattern; CT scan revealed no cerebral abnormalities. On routine biochemical investigations no abnormalities were found. There was mild mental retardation $(\mathrm{IQ}=88)$ and speech development was

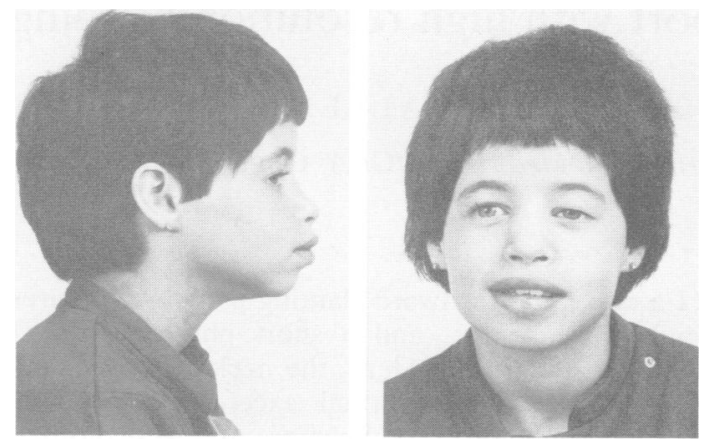

FIG 1 The proband at 7.9 years of age.

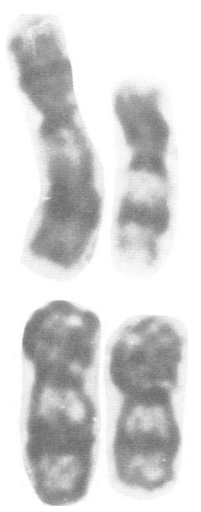

FIG 2 Chromosomes 11 of the proband (GTG banding). The right hand chromosome of each pair is the deleted 11 . distinctly retarded. Audiological investigations showed a slight hearing loss (45 dB). Dermatoglyphic analysis revealed a simian crease in the right palm and bilateral absence of the $c$ triradius.

\section{CYTOGENETIC INVESTIGATIONS}

Using GTG and RBA banding an interstitial deletion of the long arm of one of the chromosomes 11 was found, both in cultured lymphocytes (60 metaphases) and fibroblasts (100 metaphases). No metaphases with a normal karyotype were found and therefore mosaicism of del(11) seems improbable. GTG banding showed that one of the two dark bands corresponding to either q14 or q22 was lost. The karyotype thus was: $46, \mathrm{XX}, \operatorname{del}(11)(\mathrm{q} 13 \mathrm{q} 21)$ or $46, X X, \operatorname{del}(11)(q 21 q 23)$.

\section{Discussion}

The partial deletion 11q syndrome (Jacobsen syndrome) due to terminal deletions of various size (q21, q22, q23, or q24) shows, besides mental retardation, a characteristic picture consisting of trigonocephaly presenting with keel shaped forehead, ptosis, bulbous nose, and triangular shaped mouth. In the five patients with an interstitial deletion of the long arm of chromosome 11 (including our case) these signs are less pronounced or even absent (table). This finding, loss of a part of an autosome associated with normal intelligence or

TABLE Clinical findings in the $11 q-$ syndrome.

\begin{tabular}{llll}
\hline & $\begin{array}{l}\text { Terminal } \\
\text { deletion }\end{array}$ & $\begin{array}{l}\text { Interstitial } \\
\text { deletion }\end{array}$ & $\begin{array}{l}\text { Present } \\
\text { case }\end{array}$ \\
\hline Sex (F/M) & $22 / 7$ & $2 / 2$ & $\mathrm{~F}$ \\
Mean maternal age & $27 \cdot 6$ & 25 & $\mathrm{NK}$ \\
Mean paternal age & $29 \cdot 9$ & 28 & $\mathrm{NK}$ \\
Mean birth weight (g) & 2692 & 3580 & 2350 \\
Mean birth length (cm) & $47 \cdot 3$ & $52 \cdot 5$ & $\mathrm{NK}$ \\
Psychomotor retardation & $22 / 22$ & $2 / 4$ & ++ \\
Speech retardation & $9 / 9$ & $1 / 1$ & + \\
Hypertonia & $4 / 11$ & $1 / 1$ & - \\
Trigonocephaly & $20 / 25$ & $2 / 4$ & - \\
Antimongoloid slant & $10 / 23$ & $1 / 1$ & - \\
Strabismus & $4 / 5$ & $2 / 2$ & - \\
Epicanthus & $15 / 23$ & $1 / 1$ & - \\
Hypertelorism & $19 / 24$ & $2 / 2$ & + \\
Ptosis & $11 / 15$ & $0 / 1$ & $+\mathrm{R}$ \\
Flat nasal bridge & $14 / 15$ & & - \\
Short bulbous nose & $21 / 21$ & $2 / 2$ & + \\
Anteverted nostrils & $7 / 7$ & & + \\
High, narrow/cleft palate & $14 / 14$ & $2 / 2$ & + \\
Triangular shaped mouth & $18 / 19$ & $0 / 1$ & - \\
Long thin upper lip & $12 / 14$ & & - \\
Micro/retrognathia & $20 / 23$ & $1 / 2$ & - \\
Low set abnormal ears & $24 / 26$ & $3 / 3$ & - \\
Abnormal fingers/toes & $23 / 24$ & $1 / 1$ & - \\
Simian crease & $19 / 24$ & $1 / 2$ & $+\mathrm{R}$ \\
Cardiopathy & $16 / 23$ & $2 / 2$ & \\
Hearing loss & $2 / 2$ & & - \\
\hline Number informative/tol & & & - \\
\hline
\end{tabular}

Number informative/total number.

NK= not known.

$(+)=$ mild. 
mild mental retardation and relatively mild dysmorphic features, is striking. That only four patients with this deletion have been described until now could be due to the fact that in the past no chromosome analysis was done routinely in such cases. As bands q14 and q22 are of similar size and density it is not possible to determine which band is missing. Discrimination between these two bands based upon gene marker studies is not possible because, according to Shows et at and Geurts van Kessel et al, ${ }^{7}$ no genes have been assigned to either of these bands.

The authors wish to thank Ms W de Korte-Lodder and S C E Schaminee-Main for technical help in the cytogenetic studies.

\footnotetext{
References

1 Jacobsen P, Hange M, Henningsen K. An $(11,21)$ translocation in four generations with chromosome 11 abnormalities in the offspring. Hum Hered 1973;23:568-85.
}

${ }^{2}$ Taillemite JL, Baheux-Morlier G, Roux Ch. Deletion interstitielle du bras long d'un chromosome 11. Ann Genet (Paris) 1975;18:61-3

${ }^{3}$ Sørensen K, Nielsen J, Holm V, Haahr J. Fragile site long arm chromosome 16. Hum Genet 1979;48:131-4.

${ }^{4}$ McPherson E, Meissner L. 11q-syndrome: review and report of two cases. Birth Defects 1982; XVIII(3B):295-300.

5 Bateman J, Maumenee IH, Sparkes RS. Peter's anomaly associated with partial deletion of the long arm of chromosome 11. Am J Ophthalmol 1984;97:11-5.

6 Shows TB, McAlpine PJ, Miller RL. The 1983 catalogue of mapped human genetic markers and report of the nomenclature committee. Cytogenet Cell Genet 1984;37:340-93.

${ }^{7}$ Geurts van Kessel A, Tetteroo P, van Agthoven T, et al. Localization of human myeloid-associated surface antigen(s) detected by a panel of 20 monoclonal antibodies to the region q12 $\rightarrow$ qter of chromosome 11 . J Immunol 1984;133:1265-9.

Correspondence and requests for reprints to $\mathrm{J} \mathbf{M}$ Klep-de Pater, Clinical Genetics Centre, PO Box 18009, 3501 CA Utrecht, The Netherlands.

\title{
Interstitial deletion $2 \mathrm{q} 24 \cdot 3$ : case report with high resolution banding
}

\author{
JUAN BERNAR, ROBERT S SPARKES, AND SUSAN ALLENSWORTH \\ Division of Medical Genetics, Departments of Pediatrics and Medicine, UCLA Center for the Health \\ Sciences, Los Angeles, California 90024, USA.
}

SUMMARY Interstitial deletions of the long arm of chromosome 2 , involving band $2 \mathrm{q} 24$, have been described on three occasions. ${ }^{1-3} \mathrm{We}$ report our findings in a further case, in which we mapped the deletion to band $2 q 24 \cdot 3$.

\section{Case report}

The proband was the second child of nonconsanguineous parents. Both parents and a sib were in good health. Pregnancy wàs complicated by amniotic leak at about seven months, but this subsided spontaneously and did not require treatment. Delivery was at term and birth weight was $2300 \mathrm{~g}$. The umbilical cord had three vessels, but the placenta was small. The baby was brought to our attention on the second day of life because of lethargy, hypotonia, feeding difficulties, and dysmorphic features, which included microcephaly $(31.5 \mathrm{~cm})$, low set and posteriorly rotated ears, with poor formation of the upper auricular helix, short
$(1.5 \mathrm{~cm})$ and downward slanting palpebral fissures, high nasal bridge, and a short philtrum (fig 1). Micrognathia was evident, the neck was short, and the genitalia were normal except for an undescended right testis. Palmar creases were normal. Dermatoglyphs of the right hand showed arches on the index and third fingers; all others, including the left hand, were ulnar loops. During the first four months of life he improved little. He was feeding well but with some occasional regurgitation. The

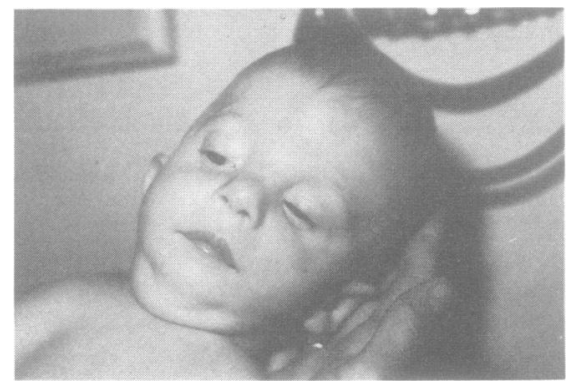

FIG 1 Proband at 4 months of age. 